\title{
Understanding the timing of Chinese border incursions into India
}

\author{
Kevin T. Greene ${ }^{1}$, Caroline Tornquist ${ }^{1}$, Robbert Fokkink ${ }^{2}$, Roy Lindelauf ${ }^{3}$ \& V. S. Subrahmanian (1) ${ }^{1 凶}$
}

Since the 1960s China and India have engaged in a dispute about the demarcation of their shared border. This territorial dispute led to a brief war in 1962, and recurring flare-ups over the following decades, including during the summer of 2020. The potential for further escalation of this dispute poses significant risks to Indian and Chinese civilians, US foreign policy objectives, and the stability of the international economic system. Despite the importance of this dispute, there have been relatively few attempts to understand the correlates of Chinese incursions. This paper addresses this important question by leveraging past work on the study of conflicts between states to derive a set of testable explanations about the impact of China-India relations, internal political affairs, international political issues, and domestic economic factors on the likelihood of incursions. The study uses 15 years of original data on monthly Chinese incursions into India along with a monthly dataset containing 18 independent variables, to develop a detailed statistical understanding of the factors that trigger Chinese incursions across the Indian border with a lead time between 1 and 6 months. The quantitative study finds that Chinese incursions are more likely when Chinese leadership is early in their tenure, but more likely when Indian leadership is in the later stages of their tenure. The results also show that closer cooperation between India and the US may trigger additional Chinese incursions into India. Finally, lower consumer confidence in the Chinese economy is consistently related to an increased likelihood of incursions. These findings have implications for the maintenance of peace and India's national security policies. Periods of Chinese uncertainty, particularly when their economy exhibits weakness and when Chinese leaders are in the early stages of their tenure are more likely to experience incursions. Further, the strengthening of the US-Indian alliance, as well as increased conflict between India and Pakistan, create the potential for an elevated risk of incursions. During these periods India should likely be on higher alert, while India and Indian allies should signal the importance of diplomatic solutions for the dispute.

\footnotetext{
${ }^{1}$ Dartmouth College, Hanover, USA. ${ }^{2}$ Technical University of Delft, Delft, Netherlands. ${ }^{3}$ Netherlands Defense Academy, Breda, Netherlands.

凶email: vs@dartmouth.edu
} 


\section{Introduction}

ince the 1960s China and India have engaged in a dispute about the exact demarcation of their shared border (the longest land border on earth). This territorial dispute led to a brief war in 1962, as well as recurring flare-ups over the following decades. During the summer of 2020, large-scale hand-tohand fighting between Chinese and Indian troops, reportedly caused by a Chinese border incursion into India, led to over 20 casualties on the Indian side and an unreported number of casualties on the Chinese side (Biswas, 2020). These casualties are the first to occur due to border disputes between the two countries in decades.

The potential for further escalation of this dispute poses significant risks to Indian and Chinese civilians, US foreign policy objectives, and to the stability of the international economic system. First, India and China are the two most populous countries in the world, each armed with nuclear weapons. The death toll of a protracted conflict between the two states would be astronomical, likely disproportionately affecting the civilian population. Second, increased tension between the two states creates a precarious situation for the United States. Overtly backing India would likely inflame US-China relations, while choosing to remain neutral would damage the US's strategic alliance with India. Third, because of the outsized roles that India and China play in the manufacturing of goods and delivery of software and other services, increased hostilities between them risks destabilizing international supply chains. The potential for loss of life and broader downstream political and economic effects of border disputes between the two states makes understanding the drivers of conflict a priority for both researchers and policymakers. Further, as China's territorial conflicts are not confined to the Indian border, but rather extend to maritime conflicts across the Pacific, building on our data collection and modeling efforts could aid in predicting and understanding other important territorial disputes such as those occurring in the Senkaku/Diaoyu islands.

We make several contributions to this question. First, we collected original monthly data on reported Chinese incursions into India. Our 15 -year dataset covering 18 independent variables is coded monthly using a specialized codebook that we developed for this purpose. The independent variables we defined leveraged past work on the study of conflicts between states and allows us to evaluate the impact of China-India (CH-IN for short) relations, internal political affairs of each country, international political issues involving each nation, as well as domestic economic factors involving each country. Each month also has a $0 / 1$ "incursion" variable telling us if there was a Chinese incursion into India reported for that month. We then conduct a detailed statistical analysis of 15 years of monthly data (2005-2019) to understand the conditions under which Chinese border incursions into India occur.

We find some support for a variety of existing explanations for state conflict. First, we see some reciprocity in the actions of China and India. During periods where the two states are in greater conflict, Chinese incursions are more likely, consistent with previous findings (Axelrod and Hamilton, 1981, Goldstein and Freeman, 1990, Ward and Widmaier, 1982). Though there has been much speculation in the press (Mastro and Tarapore, 2020) that Indian deployments along the shared $\mathrm{CH}-\mathrm{IN}$ border and/or Chinese construction in the same regions act as triggers for Chinese incursions (Tellis, 2020), our findings are mixed. Chinese construction near the border is positively linked to an incursion 5 months later but inversely linked to an incursion 2 months later. This might suggest that when Chinese construction occurs along the border, the Chinese military does not carry out incursions initially (perhaps because of concerns of heightened vigilance on the Indian side) and then -5 months later-carry out an incursion. Less clear is the issue of Indian deployments-4 months after an Indian deployment, there is evidence of a reduced likelihood of a Chinese incursion, contradicting classical border conflict theory (Sample, 1997, 1998), while 5 months after an Indian deployment, there is an increased likelihood of a Chinese incursion.

Further, there is some evidence that the interactions between other allied and rival states influence China's likelihood of launching incursions. In particular, increased cooperation between India and the United States is linked to an increase in Chinese border incursions into India, as suggested by the literature on triangular reciprocity of actions between states (Goldstein and Freeman, 1990, Ward, 1982).

Indian domestic politics also seem to influence Chinese incursions. Our study found a positive link (at the $p<0.05$ level) between Chinese incursions into India and the number of months that an Indian leader has been in power. This is contrary to past theory on border conflicts (in general, not China-India in particular) which expects that longer leader duration decreases the likelihood of conflict or conflict escalation (Bak and Palmer, 2010, Wolford, 2007, Wu and Wolford, 2018). Further, the transition of power between the center-left United Progressive Alliance (UPA) government and the more hard-line and nationalist National Democratic Alliance (NDA) party in 2014 should have created a situation where uncertainty was expected to be especially high early in the newly elected leader's tenure (Wu et al., 2020). We also find that protests in India are negatively linked to Chinese incursions. This is a surprise compared to expectations in international relations which suggest that states are more likely to engage in conflict with rivals that are undergoing episodes of domestic unrest, such as protests, as this presents a moment of vulnerability (Walt, 2013).

Chinese domestic politics also influence Chinese incursions. In contrast to the preceding finding, the number of months that a Chinese leader has been in power is inversely linked to incursions into India. This is consistent with a past theory which finds that longer leader tenure decreases uncertainty and hence decreases the risk of conflict between states (Bak and Palmer, 2010, Wolford, 2007, Wu and Wolford, 2018). Consumer confidence in the Chinese economy is inversely linked to border incursions which is consistent with the broad literature which suggests that autocratic states (in particular) may engage in international hostility to distract from poor economic conditions at home (Davies, 2002, DeRouen, 1995, Enterline and Gleditsch, 2000, Mitchell and Prins, 2004, Ward and Widmaier, 1982). This attempt to distract from domestic strife might be particularly important as China has suffered economically and diplomatically because of the Covid-19 pandemic (Pei, 2020).

\section{Literature review}

While the CH-IN border conflict has received attention from many scholars, for instance, an important recent effort is an analysis of 30 incidents involving Chinese activity along the border with India (Bhonsale, 2018), these analyses tend to be descriptive and do not provide statistical analysis. On the other hand, the previous quantitative work in international relations has not tended to focus on the CH-IN border conflict, and it is unclear if their theoretical expectations apply there. In this section, we lay out the existing expectations from scholars of both international relations and area experts. We create a series of testable hypotheses, and in further sections will use existing theory as our guide to constructing a set of variables that allow us 
to evaluate the evidence for these expectations using statistical methods.

Previous work has detailed how states tend to engage in a system of reciprocity, wherein the actions directed towards them influence their response towards other states. Put simply, cooperation between states can lead to greater cooperation in the future, while hostility can breed additional conflict (Axelrod and Hamilton, 1981). Support for this tit-for-tat strategy has been found in a variety of contexts and locations (Goldstein and Freeman, 1990, Goldstein and Pevehouse, 1997, Goldstein et al., 2001, Ward and Widmaier, 1982). This theory then suggests that periods of tension between China and India may make incursions more likely in the future. In the $\mathrm{CH}$-IN case, a specific suggested trigger is that China has invested significant resources in building border infrastructure, enabling them to mobilize their military units rapidly (Rajagopalan and Biswas, 2017). This buildup has led to confrontations with India in the past, most notably in the Doklam standoff during 2017 (Bardalai, 2018). Other work notes that the spike in Chinese incursions in recent years can be partially seen as a response to increased Indian construction near the Line of Actual Control (LAC) (Fravel, 2020). Previously, India had lagged far behind China in this area, and thus increased Indian efforts represent a significant change in the status quo. Similarly, India has also undertaken a massive effort to increase its military readiness, including establishing specific mountain divisions and reopening strategic airfields (Pandit, 2014). This buildup has also led to increased Indian patrols near the LAC, creating additional opportunities for conflict with Chinese patrols (Pant, 2014). This potential for conflict is intensified in areas where both China and India lay claim: these so-called "red zones" have featured multiple recent standoffs (Rajagopalan and Biswas, 2017). Overall, the expectation is that periods with increased tensions between China and India, either from diplomatic issues, or activities on their shared border, should increase the likelihood of incursions.

\section{Hypothesis 1: Periods of increased tension between $\mathrm{CH}-\mathrm{IN}$} are associated with a higher likelihood of incursions.

While the direct interactions between states have been found to have important impacts on behavior, only investigating dyadic interactions overlooks the broader connections within the international system. Additional research has instead made the case for studying triangular reciprocity between states. The theory suggests that states respond not only to the actions directed toward them but also to the actions directed within their alliance and rivalry networks (Goldstein and Freeman, 1990, Ward, 1982). Specifically, the CH-IN case, (Ganguly, 2018) suggests that India's growing relationship with the USA and Japan (and the related "Quadrilateral" arrangement (Graham et al., 2018) that also includes Australia) may serve as a trigger for Chinese activity along the China-India border. This notion is echoed by others who note that China is opposed to closer relations between the US and India (Rajagopalan and Biswas, 2017) and that China may see the US-India partnership as actually being aimed to contain China (Frankel, 2011). Others note that India's decision about how to leverage their relationship with the US will shape the future of the conflict (Singh, 2011). The existing literature would thus suggest that as the relationship between India and the United States becomes stronger, China may seek to undermine or test the strength of US-India cooperation.

Hypothesis 2a: Periods of increased cooperation between India and Chinese rivals are associated with a higher likelihood of incursions.

Beyond considerations of US-India cooperation, China is also involved in cooperative activities with Pakistan, a competitor of
India. It could be that incursions send a signal to Pakistan that China is nearby and ready to assist. This might be especially true for incursions that occur near territory that is contested by India and Pakistan. Similarly, increased conflict between India and Pakistan may lead to increased conflict between India and China, as China aims to defend a strategic ally.

Hypothesis 2b: Periods of increased tensions between India and Chinese allies are associated with a higher likelihood of incursions.

Others suggest that China's incursions into India are not independent actions, but rather part of a larger territorial expansion strategy. This suggests that periods, where China escalates other territorial disputes, may increase the likelihood of incursions into India (Tellis, 2020).

Hypothesis 2c: Periods of increased territorial conflict between China and other states are associated with a higher likelihood of incursions into India.

Previous literature also finds that the domestic political situation in rivals states can also impact the likelihood of international disputes. One argument (Walt, 2013) suggests that states are more likely to engage in conflict with rivals that are undergoing episodes of domestic unrest, such as civil wars, as this presents a moment of vulnerability. Domestic unrest can drain state resources and divide their focus, creating opportunities for rivals to capitalize on. While support for this theory is mixed, there is evidence that Israel's rivals are more likely to carry out attacks during periods of domestic turmoil in Israel (Derouen and Sprecher, 2006). The second explanation follows from the rational choice-based study of international conflict. This approach views conflicts as occurring because of bargaining failures between states (Fearon, 1995). While several internal events may increase uncertainty, worsening bargaining problems, the literature has particularly focused on the impact of elections and changes in leadership. Elections in rival states represent a period when uncertainty is likely to be extremely high. The potential for a new leader to take power creates uncertainly about the range of offers that the new leadership will accept and calls into question whether existing agreements will be honored (Smith and Spaniel, 2019, Wolford, 2012). ${ }^{1}$ There is evidence of increased hostility during elections in the cases of India and Pakistan (Biswas, 2020), Taiwan and China (Fravel, 2008, Ross, 2000, Wu, 2005), and the US and North Korea (Cha, 2020). Similarly, when a leader is early in their tenure uncertainly is expected to remain relatively high, increasing the likelihood of conflict relative to periods when rival leaders have been in power longer (Wolford, 2007).

Hypothesis 3a: Periods of increased unrest in Indian are associated with a higher likelihood of incursions.

\section{Hypothesis 3b: Periods of electoral uncertainly in Indian} are associated with a higher likelihood of incursions.

However, it is not only the domestic politics of India that may influence China's likelihood of engaging in incursions. Poor domestic situations such as large-scale political violence, poor electoral prospects, and economic downturns are also thought to create incentives for leaders to engage in hostility internationally to distract from their shortcomings and demonstrate capability (Davies, 2002, DeRouen, 1995, Enterline and Gleditsch, 2000, Ward and Widmaier, 1982). While some researchers have questioned the generalizability of this theory (Fordham, 2005, Leeds and Davis, 1997), (Mitchell and Prins, 2004) find that diversionary conflicts are most likely to occur between states in prolonged rivalries. Given that electoral concerns in China are less important than in democratic states and the prevalence (or at 
least the reporting) of acts of contentious politics are low, the primary expectation is that periods, where China's economic prospects are declining, should be most ripe for diversionary conflicts. It has been suggested that in the wake of the Covid-19 pandemic, China has become increasingly aggressive internationally to distract from its economic downturn (Denmark et al., 2020). Previous work also suggests economic links to past incursions. For instance, (Basrur, 2019) warns that in the aftermath of the India-China border standoff at Doklam in 2017 (Ganguly, 2017, Joshi, 2017), that "nationalism has become a critical source of legitimacy at a time when its only other source of public support-economic growth-has come under pressure"(Basrur, 2019, p. 0.16).

Hypothesis 4a: Periods of increased unrest in China are associated with a higher likelihood of incursions.

Hypothesis 4b: Periods of poor economic conditions in China are associated with a higher likelihood of incursions.

\section{Methods}

Study design and data. We test these expectations by estimating the probability of a Chinese incursion into territory on the India-China border using a compiled monthly dataset on the India-China dyad from 2005-2019. ${ }^{2}$ Our dependent variable, Chinese incursions into $\mathrm{CH}-\mathrm{IN}$ disputed territory, were manually coded using the LexisUni database, as well as from journalistic and academic sources. We define incursions as unauthorized Chinese military entries into territory that are internationally accepted as being either Indian or disputed territory. The resulting measure of incursions is a binary variable coded 1 if there was a reported instance of a Chinese incursion into Indian territory or territory that is disputed by China and India in a given month, and 0 otherwise. Our dependent variable is led between 1 and 6 months so that a model estimates the likelihood of an incursion occurring between 1 and 6 months in the future.

There are several research design decisions we have made to conduct this study. First, documenting incursions by China into India is a challenging task. The shared border, the Line of Actual Control (LAC), is not agreed upon by the two states, and in practice is not well demarcated. For this study, we rely on reports of Chinese incursions that are well documented by multiple independent media outlets. We do not record instances of incursions that are reported by the Indian government but not verified by a third party. Second, the focus of this study is on Chinese incursions into India. We make this choice for two reasons. One, while Indian foreign policy decisions play an important role in global politics, the scale of China's territorial expansion is much larger and has broader implications. Second, our research into Indian incursions into China returns few instances that could be verified by third parties. In most cases, these incursions were reported only by Chinese state media. While we do not take a position on whether the incursions happened or not, based on our coding criteria, these instances can not be included. We encourage future researchers to further investigate incursions in bordering states.

To evaluate the correlates of Chinese incursions into India and the evidence for existing theoretical explanations we construct a series of independent variables, drawn from the existing literature. Table 1 provides descriptive information on the dependent and independent variables used in our study.

We construct a variety of variables capturing the interactions between China and India, which have been suggested to increase the likelihood of conflict. First, Indian and Chinese activities around the LAC have been proposed as important explanations of

\begin{tabular}{|c|c|c|c|c|}
\hline Variable & Mean & S.D. & Min & Max \\
\hline Incursion & 0.3 & 0.5 & 0.0 & 1.0 \\
\hline $\mathrm{CH}$ construction & 0.2 & 0.4 & 0.0 & 1.0 \\
\hline $\mathrm{CH}$ deployment & 0.1 & 0.2 & 0.0 & 1.0 \\
\hline $\mathrm{CH}$ protest & 8.4 & 14.1 & 0.0 & 92.0 \\
\hline $\mathrm{CH}$ tenure & 56.9 & 29.2 & 1.0 & 116.0 \\
\hline $\mathrm{CH}$ territorial & 0.2 & 0.4 & 0.0 & 1.0 \\
\hline Econ confidence & 99.3 & 2.6 & 95.3 & 105.3 \\
\hline Econ uncertainty & 133.5 & 92.6 & 23.7 & 649.1 \\
\hline Exec meet & 0.1 & 0.2 & 0.0 & 1.0 \\
\hline IN construction & 0.4 & 0.5 & 0.0 & 1.0 \\
\hline IN deployment & 0.1 & 0.3 & 0.0 & 1.0 \\
\hline IN election & 0.1 & 0.3 & 0.0 & 1.0 \\
\hline IN internal conflict & 70.8 & 37.0 & 12.0 & 190.0 \\
\hline IN protest & 42.4 & 24.5 & 5.0 & 144.0 \\
\hline IN tenure & 53.1 & 31.9 & 1.0 & 120.0 \\
\hline IN-CH hostility & 5.5 & 8.3 & 0.0 & 53.0 \\
\hline IN-PK hostility & -3.7 & 1.9 & -10.0 & 0.0 \\
\hline IN-US cooperation & 3.4 & 1.2 & 0.0 & 8.0 \\
\hline Summer & 0.3 & 0.4 & 0.0 & 1.0 \\
\hline
\end{tabular}

Chinese incursions. As we know of no existing data covering $\mathrm{CH}-\mathrm{IN}$ activities in the border region, we coded a series of original variables detailing these activities. These measures were compiled by searching policy publications, and the LexisUni news database. First, we created a set of binary measures which are recorded 1 if there were media reports of Chinese construction activities near the disputed border, and 0 otherwise. We recorded a similar variable for Indian border construction. ${ }^{3}$ We coded another set of binary measures which are coded 1 if there were media reports of Chinese military units being deployed to the border area and 0 otherwise. We code a similar variable for India. Second, to measure the overall level of conflict between India and China we turn to the widely used Integrated Crisis Early Warning System (ICEWS) (O'Brien, 2010). ICEWS is a DARPA-funded system for automatically collecting and coding a wide variety of political events from hundreds of newspaper sources. From this dataset, we construct a variable that records the number of conflictual events that occur between India and China in a given month. ${ }^{4}$ Periods of hostility between the two states are likely to be correlated with an increased likelihood of incursions. ${ }^{5}$ While the existing literature has often focused on how military hostility may be reciprocated, this may also be true for economic actions. While our ICEWS measures capture both economic and political events, the Supplementary Materials include an additional measure capturing Indian boycotts against China. Given the importance of Chinese exports, a boycott by a large consumer such as India is a potential trigger for conflict. ${ }^{6}$ Finally, to capture interactions between the two states which may decrease the likelihood of incursions, we include variable recording meetings between the executives of the two states. This is a binary variable coded 1 if there is evidence that there was a publicly announced meeting of the executives of India and China. These meetings provide a means for the two states to discuss issues and defuse tensions. This measure includes official state visits or summits where the two leaders plan to meet in advance. This variable is coded by the authors drawing from primary source materials, policy publications, and LexisUni. This set of variables allows us to evaluate Hypothesis 1.

Our next set of variables seeks to capture the more complex interactions within India and China's broader alliance and rivalry networks. The expectation from the existing literature is increased 
conflict between India and Chinese allies or increased cooperation between India and Chinese rivals also increases the likelihood of conflict between India and China. As greater cooperation between the US and India is a frequently cited driver of Chinese aggression, we construct a variable measuring the average cooperation between the US and India in a given month. The variable is created using the ICEWS data and is constructed using the Goldstein Score (Goldstein, 1992), a widely used measure of state-state relationships. The Goldstein Score for cooperation is a continuous variable ranging from 0 to 10 . A value of 1 would represent two states having a meeting, while an 8.3 would represent a state extending military assistance to another state. We include a similar measure for a relevant Chinese ally, Pakistan. Given Pakistan's ongoing conflict with India, and their strategic alliance with China increased conflict between India and Pakistan may lead China to launch incursions. We include a variable that measures the average conflict between India and Pakistan in a given month. This measure is again drawn from ICEWS and the Goldstein Score. The Goldstein Score for hostility is continuous ranging from 0 to a -10 . For reference, a -1.9 would represent a state issuing a complaint about another state, while a -10 would be a state launching a military attack on the other state. Finally, incursions into disputed territory on the CH-IN border may be related to China's broader territorial strategy. Because there is no available information measuring Chinese incursions into other countries we rely on a proxy measure constructed from ICEWS. ${ }^{7}$ We include a binary indicator that equals 1 if there are Chinese territorial disputes with other states such as Japan, Vietnam, the Philippines, or Taiwan, in a given month. A survey of relevant policy reports suggests that these states have long-standing and salient territorial conflicts with China. This set of variables allows us to evaluate Hypotheses 2a, 2b, and 2c.

Our next set of variables aim to measure instances of domestic uncertainty and unrest within India, which have been suggested to be opportunistic periods for rivals to strike. Frequently cited examples are upcoming elections and the early period of a leader's term, as these phases are especially rife with uncertainty. First, we create a continuous variable measuring the number of months an Indian leader has been in power. Second, we create a binary variable that is equal to 1 if an India election is expected to occur in the next six months and 0 otherwise. This time frame allows for the possibility that incursions are more likely in the time leading up to an election, not just during the exact month(s) of the election. Both of these measures are drawn from the Rulers, Elections, and Irregular Governance (REIGN) data set (Bell, 2016), which records information on political leaders and elections around the world. Beyond electoral politics, domestic unrest is another variable associated with opportunistic interventions. Our first measure of domestic unrest is the number of battle deaths from internal conflict in India, recorded by the UCDP Georeferenced Event Dataset (Sundberg and Melander, 2013), the most widely used data to study internal conflicts. While many yearly studies of internal conflict create a binary variable coded 1 if there are more than 25 fatalities and 0 otherwise, there is no convention for monthly data. We thus opt for a continuous measure recording the number of "battle deaths" (non-civilian casualties) from internal conflicts in India for a given month. Another, variable suggested in the literature, are domestic protests. As India is the world's largest democracy, protests are a normal occurrence and do not necessarily represent periods of vulnerability. We instead opt for a continuous measure that records the number of violent anti-government protests in India for a given month, as these pose a larger threat to the state. The variable is taken from ICEWS. This set of variables allows us to evaluate Hypotheses 3a and 3b.
Our next set of variables aim to evaluate evidence for existing theories which suggest that states are more likely to act aggressively towards rivals to distract from their own domestic uncertainty. Again key variables which have been suggested to create uncertainty are upcoming elections and the periods early in a leader's tenure. We thus create a continuous variable measuring the number of months a Chinese leader has been in power. This measure is drawn from the Rulers, Elections, and Irregular Governance (REIGN) data set (Bell, 2016). Unlike in the Indian case, executive elections are not a feature of the Chinese political system and thus this variable is not included. Beyond electoral politics, domestic unrest has also been suggested to create incentives for diversionary conflict. Similar to the measure created for India we also opt for a continuous measure that records the number of violent anti-government protests in China for a given month. The variable is taken from ICEWS. Unlike in the Indian case, we opt not to include a variable recording the battle deaths from internal conflict. We make this choice because there are almost no months that have recorded battle deaths and hence there is little that can be said about it from a statistical perspective. Given the importance of economic issues on Chinese decision-making, we also include two economic measures which have been suggested to create incentives for diversionary conflicts. The first is a measure of the uncertainly in the Chinese economy. The measure is based on the monthly amount of articles about economic uncertainty in two major Chinese newspapers. These values are taken from the Federal Reserve Bank of St. Louis (FRED) and calculated based on the approach developed by (Davis et al., 2019). As these papers are state-controlled this provides an indirect measure of the Chinese government's level of expressed economic uncertainty. The second is a continuous variable measuring consumer confidence in the Chinese economy. The measure uses the consumer confidence index (CCI) measure taken from (OECD, 2015). The measure is an index computed from a series of survey questions answered monthly from a sample of Chinese households. The measure is normalized so that values below 100 indicate pessimistic feelings towards the economy while values greater than 100 indicate optimistic feelings about the economy. ${ }^{8}$ While we should be careful about assuming that this is a truthful estimation of the beliefs of the Chinese public, it does provide an additional measure of economic uncertainty that is not explicitly linked to the Chinese government. This set of variables allows us to evaluate Hypotheses $4 \mathrm{a}$ and $4 \mathrm{~b}$.

Because of the potential for our results to be influenced by temporal effects, which may lead to spurious results, we account for this in two ways. First, we include a time counter in our model which increments from 1 to the maximum number of observations in the study. This allows us to control for a linear time trend in the data (Wooldridge, 2016). Second, we account for possible seasonality. We add a binary variable coded 1 if the observation falls in the months June, July, and August and 0 otherwise. This feature has been added both due to Indian officials frequently issuing statements that Chinese incursions are a common summer occurrence and because of the difficulty of traversing much of the border region during cooler months.

Statistical methods. To assess the impact of these proposed features on the likelihood of Chinese incursions we estimated logistic models regressing an indicator for whether a Chinese border incursion occurred in a given month on a series of variables drawn from the existing literature. ${ }^{9}$ Our approach is consistent with the assumptions of binary logit. We estimate the correlations between features and the variance inflation factor (VIF) and find no evidence of multicollinearity among our features. 
Table 2 Estimated coefficients.

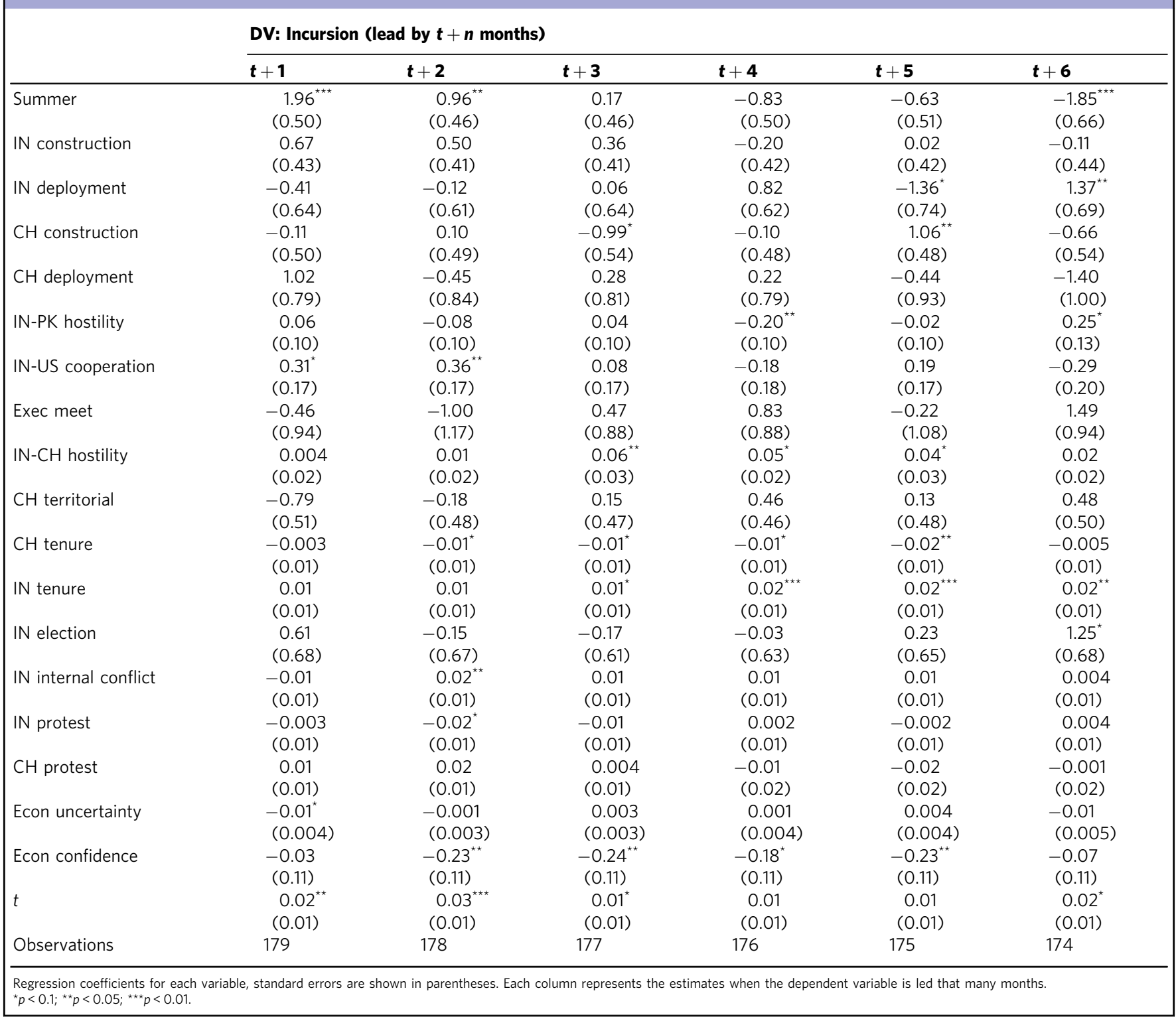

\section{Results}

Table 2 presents our full regression results. We begin with our findings for the variables measuring reciprocity between Chinese and Indian actions. We see that in the majority of models, our measure of hostility between China and India is positively associated with Chinese border incursions. Chinese incursions into India are more likely when the two states are involved in greater conflict. ${ }^{10}$ Other proposed measures of Indian and Chinese activities around the border area are less conclusive. Our estimate of the impact of Chinese construction near the disputed border with India when led three months is negative $(\beta=-0.99$; $p=0.07)$, while at a lead of 5 months it is positive $(\beta=1.06$; $p=0.03$ ). Our general expectation was that Chinese construction should increase the likelihood of incursions as this creates friction between Indian and Chinese border troops. The second inconsistent finding is from our measure of Indian military deployments near the border. When our outcome variable is led five months the estimate is negative $(\beta=-1.36 ; p=0.07)$, while at lead 6 it is positive $(\beta=1.37 ; p=0.05)$. Here again, existing work would have expected deployments to raise tensions, leading to an increased likelihood of an incursion occurring.

Next, we turn to the impact of India and China's alliances and rivalries. First, we see a positive effect for our measure of cooperation between India and the United States for leads of 1 month $(\beta=0.31 ; p=0.08)$ and 2 months $(\beta=0.36 ; p=0.04)$ in the future. Our estimates suggest that as India and the US engage in more cooperation, China is more likely to carry out an incursion. The aligns with previous expectations that the US-Indian relationship is an important factor in Chinese incursions. Second, we find an inconsistent relationship between hostility among India and Pakistan and Chinese incursions. We find a negative relationship for incursions 4 months in the future. However, because the measure is scaled such that larger negative numbers represent increased hostility, in effect when hostility between India and Pakistan decreases Chinese incursions are less likely. However, for incursions 6 months in the future, we observe a positive relationship, meaning that when hostility between India and Pakistan decreases Chinese incursions are more likely. 
Next, we turn to the impact of domestic unrest in India on the likelihood of Chinese incursions. First, we observe that rather than domestic protest in India being associated with an increased likelihood of incursions, they are negatively associated $(\beta=$ $-0.02 ; p=0.09)$. We should note that the substantive impact is relatively small while the variable is only marginally significant. Second, we see that internal conflicts are significantly $(\beta=0.02$; $p=0.03$ ) associated with an increased likelihood of incursions 2 months in the future, consistent with previous explanations.

There is also evidence of an impact of Indian electoral politics on the likelihood of Chinese incursions. First, we see that upcoming Indian elections are positively $(\beta=1.25 ; p=0.07)$ associated with Chinese incursions 6 months in the future. Second, in leads between three and six months, the tenure of Indian leaders $(\beta=0.02 ; p=0.01)$ increases, rather than decreases the likelihood of Chinese incursions. As the tenure measure increments monthly, the relatively small effect would still result in the odds of a Chinese incursion increasing by more than 50 percent at the time a Prime Minister was re-elected to serve a second term (after 60 months or 5 years had passed). Given the long-standing tensions between China and India, it could be that China does not engage in incursions during the early tenure of Indian leaders as this may lead Indian leaders to respond aggressively to demonstrate their resolve.

Next, we turn to the impact of Chinese domestic politics. First, we find that in leads of 2-5 months, Chinese leader tenure is negatively associated with the probability of observing a Chinese border incursion $(\beta=-0.02 ; p=0.01)$. This is the opposite effect of what we observe from our estimates of Indian leader tenure but is consistent with existing expectations. Another finding consistent with previous work is that poor economic conditions in China are associated with increased incursions at nearly every lead. Our measure for consumer confidence in the Chinese economy is negative and significant at leads $1,2,3$, and 6, meaning that as there is more confidence in the economy incursions are less likely to be carried out. The largest effect is seen for lead $3(\beta=-.24 ; p=0.04)$. Interestingly, expressed uncertainty in the Chinese economy is most often not significant at conventional levels. The one exception is at lead 1 , where we observe a negative and significant relationship $(\beta=-0.01$; $p=0.07)$. This suggests that as expressed uncertainty in the Chinese economy increases, incursions are less likely to be carried out during the following month, possibly suggesting a gathering of resources in the early stages of economic downturns.

\section{Discussion}

The results have important policy implications-both for the maintenance of peace and for India's national security policies. World leaders and India's military should be on high alert when China's economy exhibits weakness and when Chinese leaders are in the early stages of their tenure. These are periods of a heightened risk of Chinese incursions into India-and so India and its allies should take preemptive steps to signal to China that they are strong and will not tolerate incursions.

Our results also statistically show that strengthening the US-India relations will also likely increase Chinese incursions over the next 6 months. Though the relationship between Chinese construction along the shared border with India and future incursions is mixed, India should monitor the border better. This may be aligned with the idea of strengthening the US-India relations as the US has a wealth of high-end surveillance technology to offer in order to better monitor Chinese construction along the China-India border. Stronger intelligence cooperation with Australia has also been suggested (White, 2020).
India's military also needs to be prepared for incursions when there are increased hostilities between India and China, as well as between India and Pakistan.

\section{Conclusion and future work}

This is among the first comprehensive, data-driven study of Chinese incursions into Indian territory. Using an original 15-year data set at the monthly level, we derive conditions that are statistically linked to Chinese incursions into India with a lead of 1-6 months.

This paper seeks to understand the conditions that are linked to Chinese incursions into India in the next few months. An important next step is to understand how these findings can help shape a security posture, undertaken either by India alone or by India and its allies, in order to reduce such incursions. China has a number of instruments (e.g., economic boycotts) that can adversely affect some of India's allies, should they adopt a more cooperative stance. This will be the focus of important future work.

\section{Data availability}

The datasets analyzed during this study are available in the Dataverse repository: https://doi.org/10.7910/DVN/DQJEGU.

Received: 28 January 2021; Accepted: 7 June 2021; Published online: 05 July 2021

\section{Notes}

1 This uncertainty is only compounded as election periods also see an increase in nationalist rhetoric ( $\mathrm{Wu}, 2005)$

2 A detailed codebook is provided in the Supplemental Materials.

3 While large-scale improvements to the road network along the India-China border were approved by the Indian government in 2006 , the month-to-month progress of this construction is often inconsistent or unclear. Thus this variable should be seen not as a measure of India's actual construction efforts, but rather the announcement that major projects are starting or finishing.

4 To ensure there is no data leakage between this feature and the outcome, we exclude events coded as "Mobilize or increase armed forces", and "Occupy territory."

5 While other variables measuring the median or max level of conflict would also be appropriate, we find these variables are very highly correlated with Chinese economic variables, creating the potential for multicollinearity issues.

6 We find this variable to be statistically insignificant at all lead values.

7 Specifically we use the events coded as "Mobilize or increase armed forces", or "Occupy territory" and where China is the perpetrator.

8 In other models, the value of Chinese exports and imports in a given month was also used. However, these variables were very highly correlated both with one another and with other variables in the model. Thus to reduce potential issues of multicollinearity these measures were not included in our final set of analyses.

9 This estimation is done using the glm package in R.

10 Importantly events related to border incursion were removed from our measure to ensure there was no leakage between or independent and dependent variables.

\section{References}

Axelrod R, Hamilton W (1981) The evolution of cooperation. Science 211 (4489):1390-1396

Bak D, Palmer G (2010) Testing the Biden hypotheses: leader tenure, age, and international conflict. Foreign Policy Anal 6(3):257-273

Bardalai AK (2018) Doklam and the indo-china boundary. J Defence Stud 12 (1):5-13

Basrur R (2019) India and china: a managed nuclear rivalry? Washington Quart 42 (3):151-170

Bell C (2016) The rulers, elections, and irregular governance dataset (REIGN). https://oefdatascience.github.io/REIGN.github.io/

Bhonsale M (2018) Understanding Sino-Indian border issues: an analysis of incidents. ORF Occasional Paper

Biswas S (2020) India-China clash: 20 Indian troops killed in Ladakh fighting. BBC News

Brandt P, Freeman J, Lin T, Schrodt P (2012) A Bayesian time series approach to the comparison of conflict dynamics. In APSA 2012 Annual Meeting Paper 
Cha V (2020) North Korean provocations likely around us presidential election. CSIS Korea Chair: Beyond Parallel. https://beyondparallel.csis.org/dprkprovocations-likely-around-u-s-presidential-election/

Davies G (2002) Domestic strife and the initiation of international conflicts: a directed dyad analysis, 1950-1982. J Conflict Resol 46(5):672-692

Davis S, Liu D, Sheng X (2019) Economic policy uncertainty in china since 1949: The view from mainland newspapers. Technical Report

Denmark A, Edel C, Mohandas S (2020) Same as it ever was: china's pandemic opportumism on it's periphery. War on The Rocks

DeRouen Jr K (1995) The indirect link: politics, the economy, and the use of force. J Conflict Resol 39(4):671-695

Derouen K, Sprecher C (2006) Arab behaviour towards Israel: strategic avoidance or exploiting opportunities? Br J Polit Sci 36(3):549-560

Enterline A, Gleditsch K (2000) Threats, opportunity, and force: repression and diversion of domestic pressure, 1948-1982. Int Interact 26(1):21-53

Fearon J (1995) Rationalist explanations for war. Int Organizat 49(3):379-414

Fordham B (2005) Strategic conflict avoidance and the diversionary use of force. J Politics 67(1):132-153

Frankel F (2011) The breakout of China-India strategic rivalry in Asia and the Indian ocean J Int Affairs 64(2):1-17

Fravel T (2008) Power shifts and escalation: explaining china's use of force in territorial disputes. Int Security 32(3):44-83

Fravel T (2020) China and the border dispute with India after 1962. In: Routledge Handbook of China-India Relations. Routledge

Ganguly S (2017) The doklam dispute in context. Foreign Affairs. https://www. foreignaffairs.com/articles/asia/2017-08-09/doklam-dispute-context

Ganguly S (2018) India and china: on a collision course? Pacific Affairs 91(2):231-244

Goldstein J (1992) A conflict-cooperation scale for WEIS events data. J Conflict Resol 36(2):369-385

Goldstein J, Freeman J (1990) Three-way street: strategic reciprocity in world politics. University of Chicago Press

Goldstein J, Pevehouse J (1997) Reciprocity, bullying, and international cooperation: time-series analysis of the Bosnia conflict. Am Polit Sci Rev 91(3):515-529

Goldstein J, Pevehouse J, Gerner D, Telhami S (2001) Reciprocity, triangularity, and cooperation in the middle east, 1979-97. J Conflict Resol 45(5):594-620

Graham E, Pan C, Hall I, Kersten R, Zala B, Percy S (2018) Debating the quad. Strategic and Defence Studies Centre, Australian National University

Joshi M (2017) Doklam: to start at the very beginning. ORF Special Report

Leeds BA, Davis D (1997) Domestic political vulnerability and international disputes. J Conflict Resol 41(6):814-834

Mastro O, Tarapore A (2020) Asymmetric but uneven: the China-India conventional military balance. In Kanti Bajpai, Selina Ho, and Manjari Chatterjee Miller (eds), Routledge Handbook of China-India Relations. Routledge, London, pp. 235-247

Mitchell S, Prins B (2004) Rivalry and diversionary uses of force. J Conflict Resol 48 (6):937-961

OECD (2015) Main economic indicators-complete database. https://doi.org/ $10.1787 /$ mei-data-en

O'Brien S (2010) Crisis early warning and decision support: contemporary approaches and thoughts on future research. Int Stud Rev 12(1):87-104

Pandit R (2014) Army kicks off raising new mountain strike corps against China. Times of India

Pant $\mathrm{H}$ (2014) Why border stand-offs between India and China are increasing. $B B C$ News

Pei M (2020) China's coming upheaval: competition, the coronavirus, and the weakness of Xi Jinping. Foreign Affairs 99:82

Rajagopalan R, Biswas A (2017) India-China relations under xi Jinping: an Indian perspective. China Int J 15(1):120-139

Ross R (2000) The 1995-96 Taiwan strait confrontation: coercion, credibility, and the use of force. Int Security 25(2):87-123

Sample S (1997) Arms races and dispute escalation: resolving the debate. J Peace Res 34(1):7-22
Sample S (1998) Military buildups, war, and realpolitik: a multivariate model. J Conflict Resol 42(2):156-175

Singh ZD (2011) After the hiatus: India-China border diplomacy since the 1970s. China Rep 47(2):83-98

Smith B, Spaniel W (2019) Militarized disputes, uncertainty, and leader tenure. J Conflict Resol 63(5):1222-1252

Sundberg R, Melander E (2013) Introducing the UCDP georeferenced event dataset. J Peace Res 50(4):523-532

Tellis A (2020) Hustling in the Himalayas: the Sino-Indian border confrontation. Carnegie Endowment for International Peace

Walt S (2013) Revolution and war. Cornell University Press

Ward M, Widmaier U (1982) The domestic-international conflict nexus: new evidence and old hypotheses. Int Interact 9(1):75-101

Ward M (1982) Cooperation and conflict in foreign policy behavior: reaction and memory. Int Stud Quart 26(1):87-126

White M (2020) A natural partner? intelligence cooperation with India and Australia as regional interests. Security Challenges 16(2):88-105

Wolford S (2007) The turnover trap: new leaders, reputation, and international conflict. Am J Polit Sci 51(4):772-788

Wolford S (2012) Incumbents, successors, and crisis bargaining: leadership turnover as a commitment problem. J Peace Res 49(4):517-530

Wooldridge J (2016) Introductory econometrics: a modern approach. Nelson Education. https://www.cengage.com/c/introductory-econometrics-a-modernapproach-6e-wooldridge/9781305270107/

Wu C, Licht A, Wolford S (2020) Same as the old boss? domestic politics and the turnover trap Int Stud Quart 65(1):173-183

Wu C, Wolford S (2018) Leaders, states, and reputations. J Conflict Resol 62 (10):2087-2117

Wu Y (2005) Taiwan's domestic politics and cross-strait relations China J 53:35-60

\section{Competing interests}

The authors declare no competing interests.

\section{Additional information}

Supplementary information The online version contains supplementary material available at https://doi.org/10.1057/s41599-021-00843-5

Correspondence and requests for materials should be addressed to V.S.S.

Reprints and permission information is available at http://www.nature.com/reprints

Publisher's note Springer Nature remains neutral with regard to jurisdictional claims in published maps and institutional affiliations.

Open Access This article is licensed under a Creative Commons Attribution 4.0 International License, which permits use, sharing, adaptation, distribution and reproduction in any medium or format, as long as you give appropriate credit to the original author(s) and the source, provide a link to the Creative Commons license, and indicate if changes were made. The images or other third party material in this article are included in the article's Creative Commons license, unless indicated otherwise in a credit line to the material. If material is not included in the article's Creative Commons license and your intended use is not permitted by statutory regulation or exceeds the permitted use, you will need to obtain permission directly from the copyright holder. To view a copy of this license, visit http://creativecommons.org/ licenses/by/4.0/.

(C) The Author(s) 2021 